University of Nebraska - Lincoln

DigitalCommons@University of Nebraska - Lincoln

Faculty Publications from the Center for Plant

Science Innovation

Plant Science Innovation, Center for

1996

\title{
Phosphoenolpyruvate Carboxylase: A Ubiquitous, Highly Regulated Enzyme in Plants
}

\author{
Raymond Chollet \\ University of Nebraska - Lincoln, rchollet1@unl.edu \\ Jean Vidal \\ Université de Paris-Sud \\ Marion H. O'Leary \\ University of Nebraska - Lincoln
}

Follow this and additional works at: https://digitalcommons.unl.edu/plantscifacpub

Part of the Plant Sciences Commons

Chollet, Raymond; Vidal, Jean; and O'Leary, Marion H., "Phosphoenolpyruvate Carboxylase: A Ubiquitous, Highly Regulated Enzyme in Plants" (1996). Faculty Publications from the Center for Plant Science Innovation. 42.

https://digitalcommons.unl.edu/plantscifacpub/42

This Article is brought to you for free and open access by the Plant Science Innovation, Center for at DigitalCommons@University of Nebraska - Lincoln. It has been accepted for inclusion in Faculty Publications from the Center for Plant Science Innovation by an authorized administrator of DigitalCommons@University of Nebraska Lincoln. 


\title{
Phosphoenolpyruvate Carboxylase: A Ubiquitous, Highly Regulated Enzyme in Plants
}

\author{
Raymond Chollet \\ Department of Biochemistry, \\ University of Nebraska-Lincoln, \\ Lincoln, NE 68588-0664, USA \\ Jean Vidal \\ UA CNRS D-1128, Institut de Biotechnologie des Plantes, \\ Université de Paris-Sud, \\ Orsay Cedex, 91405 France

\section{Marion H. O'Leary} \\ Department of Biochemistry, \\ University of Nebraska-Lincoln, \\ Lincoln, NE 68588-0664, USA
}

\begin{abstract}
Since plant phosphoenolpyruvate carboxylase (PEPC) was last reviewed in the Annual Review of Plant Physiology over a decade ago (O'Leary 1982), significant advances have been made in our knowledge of this oligomeric, cytosolic enzyme. This review highlights this exciting progress in plant PEPC research by focusing on the three major areas of recent investigation: the enzymology of the protein; its posttranslational regulation by reversible protein phosphorylation and opposing metabolite effectors; and the structure, expression, and molecular evolution of the nuclear PEPC genes. It is hoped that the next ten years will be equally enlightening, especially with respect to the three-dimensional structure of the plant enzyme, the molecular analysis of its highly regulated protein-Ser/ Thr kinase, and the elucidation of its associated signal-transduction pathways in various plant cell types.
\end{abstract}

Keywords: PEP carboxylase (PEPC), catalytic reaction mechanism, regulatory protein phosphorylation, gene structure, expression, and evolution 


\section{Contents}

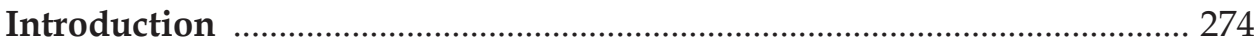

Enzymology Of PEP Carboxylase ...................................................................2275

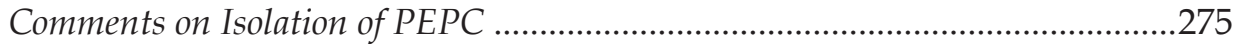

Carboxylation and Hydrolysis of PEP Analog ……………..............................275

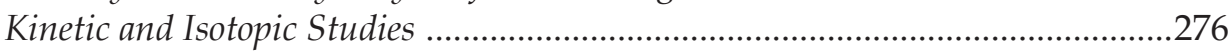

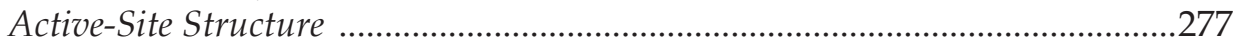

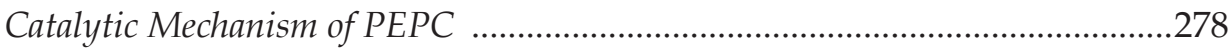

Posttranslational Regulation of PEP-Carboxylase Activity ..........................280

Regulatory Phosphorylation of Photosynthetic PEPC .........................................281

Regulatory Phosphorylation of Nonphotosynthetic PEPC Isoforms .....................284

Other Proposed Regulatory Mechanisms ............................................................285

PEPC Gene Structure, Expression, and Molecular Evolution …………......286

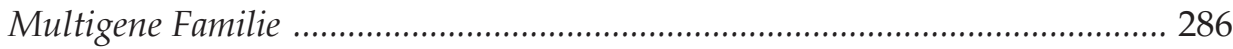

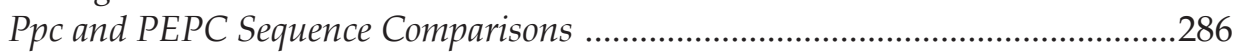

Ppc Promoter Analysis and Transcription ........................................................287

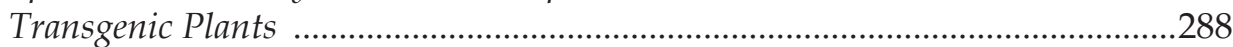

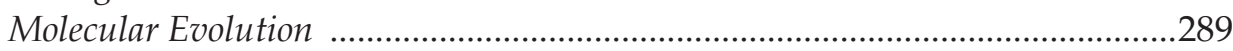

Conclusions and Future Prospects ................................................................... 291

\section{Introduction}

Phosphoenolpyruvate carboxylase (PEPC; EC 4.1.1.31) is a ubiquitous cytosolic enzyme in higher plants and is also widely distributed in bacteria, cyanobacteria, and green algae $(68,114)$. It catalyzes the irreversible $\beta$-carboxylation of Phosphoenolpyruvate (PEP) in the presence of $\mathrm{HCO}_{3}{ }^{-}$and $\mathrm{Me}^{2+}$ to yield oxaloacetate (OAA) and $\mathrm{Pi}$ and thus is involved intimately in $\mathrm{C}_{4}$-dicarboxylic acid metabolism in plants. Besides its cardinal roles in the initial fixation of atmospheric $\mathrm{CO}_{2}$ during $\mathrm{C}_{4}$ photosynthesis and Crassulacean acid metabolism (CAM), PEPC functions anaplerotically in a variety of nonphotosynthetic systems such as $\mathrm{C} / \mathrm{N}$ partitioning in $\mathrm{C}_{3}$ leaves, seed formation and germination, and fruit ripening $(66,68)$. Nonphotosynthetic isoforms of PEPC also play specialized roles in guard-cell C metabolism during stomatal opening (90) and plant host-cell $\mathrm{C}_{4}$-acid formation in $\mathrm{N}_{2}$-fixing legume root nodules $(19,115)$.

Since 1982, when PEPC was reviewed last in the Annual Review of Plant Physiology (87), many new and significant findings about this oligomeric enzyme have been made. In addition to the further elucidation of its catalytic reaction mechanism and the initiation of structure-function analyses by sitedirected mutagenesis, there has been an explosion in research related to the posttranslational regulation of the enzyme's activity and allosteric properties by reversible protein phosphorylation and to PEPC gene $(P p c)$ structure, expression, and molecular evolution. These exciting new advances in plant PEPC research are the primary focus of this review, while only limited refer- 
ence will be made to the microbial enzyme. The interested reader should consult earlier reviews on PEPC for additional breadth and detail $(3,19,35,54$, $68,84,87,90,96,104,114,117)$.

\section{Enzymology of PEP Carboxylase}

\section{Comments on Isolation of PEPC}

It is now amply documented that native leaf and recombinant forms of PEPC are highly susceptible to limited proteolysis near the N-terminus during extraction and subsequent purification $(6,9,23,77,82,121)$. While such modification has no major influence on the enzyme's electrophoretic mobility, $\mathrm{V}_{\text {max }}$ and carbon-isotope effects, removal of this plant-invariant N-terminal domain markedly decreases the in vitro phosphorylatability and sensitivity of PEPC to its negative allosteric effector L-malate. Thus, it is our view that many earlier kinetic analyses of purified or commercial plant PEPC have probably been compromised by this N-terminal truncation (see comments in 23, 54, 68). More recent studies have preserved the enzyme's integrity during isolation by the inclusion of glycerol, L-malate, and proteinase inhibitors (especially chymostatin) and by the use of rapid purification protocols that exploit fast-protein liquid chromatography, HPLC, or immunochromatography $(4,7,9,23,58,77,82,119$, $121,136)$. With such strategies, preparations of intact, $\mathrm{N}$-blocked leaf $\left(\mathrm{C}_{4^{\prime}} \mathrm{CAM}\right.$, $\mathrm{C}_{3}$ ), nodule, and recombinant PEPC are readily obtained.

\section{Carboxylation and Hydrolysis of PEP Analogs}

A variety of PEP analogs have been examined as substrates for $C_{4}$ PEPC (see 35 and Table 1). Although a number of compounds are processed by the en-

Table 1. Activity of PEP analogs with PEPC ${ }^{a}$

\begin{tabular}{lcccc}
\hline Compound & Vmax $(\mathrm{rel})^{\mathrm{b}}$ & \% Carboxylation & \% Hydrolysis & References \\
\hline PEP & 100 & 97 & 3 & 6 \\
(E)-3-fluoro-PEP & 5 & 86 & 14 & 32,50 \\
(Z)-3-fluoro-PEP & 5 & 3 & 97 & 32,50 \\
(Z)-3-chloro-PEP & 25 & 25 & 75 & 71 \\
Alleno-PEP & 90 & 0 & 100 & 126 \\
Thio-PEP & 9 & 0 & 100 & 103 \\
(Z)-3-methyl-PEP & 4 & 0 & 100 & $31,33,34,86$ \\
(Z)-3-bromo-PEP & 25 & 0 & 100 & 21 \\
3,3-dimethyl-PEP & 2 & 0 & 100 & 31 \\
\hline
\end{tabular}

\footnotetext{
a Values given are for the maize leaf enzyme in the presence of Mg2+.

${ }^{\mathrm{b}}$ Carboxylation plus hydrolysis.
} 
zyme, most are not carboxylated but instead are hydrolyzed to pyruvate derivatives (Equation 1) by a mechanism that shares several steps with catalysis (see section on Catalytic Mechanism of PEPC). This phosphatase activity is probably not related to the much slower bicarbonate-independent hydrolysis of phosphoglycolate and phospholactate that is also catalyzed by the enzyme $(48,50)$.

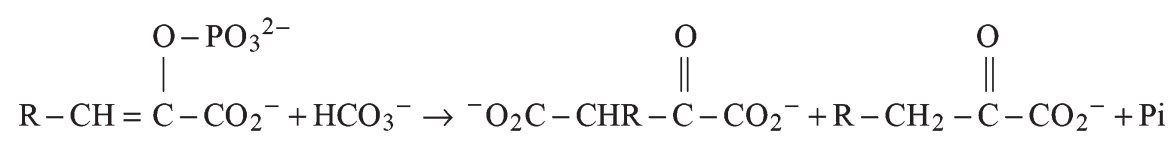

PEP itself also undergoes a few percent of an $\mathrm{HCO}_{3}{ }^{-}$-dependent pyruvate formation. This hydrolysis is a minor component of the overall reaction flux with $\mathrm{Mg}^{2+}$ under in vivo conditions $(<5 \%)$, but it increases with other metal ions and constitutes over $50 \%$ of the total reaction flux when $\mathrm{Ni}^{2+}$ is used (6). Interestingly, the PEP analog in which the phosphate has been replaced by a sulfate is not a substrate for the enzyme and, in fact, this compound does not bind to the active site [but it is a substrate for pyruvate kinase (93)].

Functional analogs for $\mathrm{CO}_{2}$ and $\mathrm{HCO}_{3}^{-}$are rare in enzymatic reactions. In the case of PEPC, $\mathrm{HCO}_{2}{ }^{-}$can replace $\mathrm{HCO}_{3}{ }^{-}$, forming formyl-P and pyruvate at a rate that is about $1 \%$ of that for PEP carboxylation (48).

\section{Kinetic and Isotopic Studies}

Early thinking about the catalytic mechanism was dominated by the seminal observation of Maruyama et al (72) [recently confirmed by O'Leary \& Hermes (88)] that ${ }^{18} \mathrm{O}$-labeled $\mathrm{HCO}_{3}{ }^{-}$gives products containing one equivalent of ${ }^{18} \mathrm{O}$ in $\mathrm{Pi}$ and two in the $\mathrm{\gamma}$-carboxyl of OAA. This isotope transfer persists with a number of other substrates, including those that undergo hydrolysis rather than carboxylation. (Z)-3-methyl-PEP gives more than one equivalent of ${ }^{18} \mathrm{O}$ in $\mathrm{Pi}$ and also gives ${ }^{18} \mathrm{O}$ incorporation into reisolated starting material after partial reaction $(29,86)$. A similar phenomenon is observed with 3 -fluoroPEP; exchange is eight times faster than substrate consumption (50). These observations indicate that the initial steps in the carboxylation mechanism are reversible (see section on Catalytic Mechanism of PEPC).

PEPC has been subjected to a variety of kinetic studies over the years, but these have generally been qualitative in nature because investigators failed to rigorously control $\mathrm{HCO}_{3}{ }^{-}$concentrations and to account for the presence of PEP-metal complexes. Recent studies of initial velocity patterns varying the two substrates and $\mathrm{Me}^{2+}$ indicate that there is a high level of synergism in the binding of substrates (49). $\mathrm{Mg}^{2+}$ binds first, and this binding is at equilibrium; PEP binds second; $\mathrm{HCO}_{3}{ }^{-}$binds third; and all three have to be present before the reaction begins. 
The small carbon-isotope effect $\left(\mathrm{k}^{12} / \mathrm{k}^{13}=1.003\right)$ that accompanies the carboxylation of PEP by PEPC has been of interest in connection with studies of isotope fractionation in plants (28). The carbon-isotope fractionation by PEPC is independent of the phosphorylation state of the enzyme and the presence or absence of the N-terminal phosphorylation domain, and nearly independent of $\mathrm{pH}$ (50, 89, 124; P Paneth \& S Madhavan, unpublished data). This fractionation is small compared to what would be expected if $\mathrm{C}-\mathrm{C}$ bond formation were simply rate determining. Instead, some step prior to $\mathrm{C}-\mathrm{C}$ bond formation must be rate limiting.

The oxygen-isotope effect for the bridging oxygen of PEP is large $\left(\mathrm{k}^{16} / \mathrm{k}^{18}\right.$ = 1.0056) when the $\mathrm{HCO}_{3}{ }^{-}$concentration is low, but the value decreases to 0.994 at high $\left[\mathrm{HCO}_{3}^{-}\right]$, consistent with the ordered stepwise mechanism given below (30). Deuterium-isotope effects for PEP-3,3- $\mathrm{d}_{2}$ are 0.94 on $V$ and 0.95 on $V / K$, also consistent with the stepwise mechanism (D Arnelle \& $\mathrm{MH} \mathrm{O}^{\prime}$ Leary, unpublished data).

Carbon-isotope effects on the $(E)$ and $(Z)$ isomers of 3-fluoro-PEP provide an interesting contrast $(50)$. The $(E)$ isomer has a small carbon-isotope effect (1.009), consistent with rate-determination phosphate transfer. However, the $(Z)$ isomer [which mostly gives hydrolysis rather than carboxylation (Table 1)] shows a large isotope effect (1.049), which is apparently associated with the loss of $\mathrm{CO}_{2}$ from the complex during catalysis.

Several stereochemical probes have been used to define PEPC catalysis. Early work by Rose et al (97) demonstrated that carboxylation of PEP occurs on the si face of the substrate, and carboxylation of the two isomers of 3-fluoro-PEP occurs on the same face (50). When (Z)-3-methyl-PEP is hydrolyzed by PEPC in $\mathrm{D}_{2} \mathrm{O}$, the 3-D-a-ketobutyrate that is produced is racemic, which indicates that protonation of the enolate occurs in solution rather than on the surface of the enzyme (33). The stereochemistry of substitution at phosphorus can be determined by using PEP containing $\mathrm{S},{ }^{16} \mathrm{O}$, and ${ }^{17} \mathrm{O}$ in nonbridging positions of the phosphate ester. Carboxylation in $\mathrm{H}_{2}{ }^{18} \mathrm{O}$ produces a chiral thiophosphate with inversion of configuration at phosphorus (39). Thus, substitution at phosphorus occurs by an in-line mechanism.

\section{Active-Site Structure}

Mn-EPR studies of PEPC with PEP and various substrate analogs suggest that PEP itself is bidentate coordinated to the metal. Metal coordination in the enolate intermediate is to the enolate oxygen, the carboxyl oxygen, and a phosphate oxygen (5).

Results of chemical modification studies on various plant PEPCs with group-selective reagents have suggested that Cys, His, Arg, and Lys are essential for activity $(3,96,104)$. To date, only one such residue has been identified in the plant primary structure-Lys-606 in maize PEPC (57). Further- 
more, the complete absence of Cys in PEPC from Thermus sp., a thermophilic bacterium, excludes the direct involvement of these residues in catalysis (79A). Site-directed mutagenesis studies of the active-site domain of PEPC have thus far been performed only with the enzyme from Escherichia coli. His138 (E. coli numbering) is required for carboxylation, but the mutant H138N is able to catalyze PEP hydrolysis to pyruvate in the presence of $\mathrm{HCO}_{3}{ }^{-}(109$, 112). His-579 is not obligatory for catalysis, in spite of the fact that it is species- invariant (111). Replacement of conserved Arg-587 by Ser also gives an enzyme that catalyzes hydrolysis, but not carboxylation $(112,134)$. Figure 1 indicates these targeted, species-invariant Lys, His, and Arg residues in the deduced primary structure of Sorghum $\mathrm{C}_{4}$ PEPC.

Along with site-directed mutagenesis, X-ray crystallography has become the sine qua non of enzymology. Alas, PEPC does not yet seem to have yielded to the efforts of crystallographers. The E. coli enzyme has been reported to give crystals that diffract X-rays (46). We are also aware of attempts in other laboratories to obtain diffraction-quality crystals of recombinant PEPC from various plant sources, but no substantial progress in this area has been reported.

\section{Catalytic Mechanism of PEPC}

The information cited above permits presentation of a relatively convincing mechanism for action of PEPC (Figure 2). Substrates and $\mathrm{Me}^{2+}$ bind in the preferred order metal, $\mathrm{PEP}, \mathrm{HCO}_{3}{ }^{-}$. The first chemical step is phosphate transfer to form carboxyphosphate and the enolate of pyruvate, as perhaps first suggested by Walsh (118). Stereochemical studies require that the transition state for this step is linear at phosphorus; thus, the carbonyl carbon in the intermediate carboxyphosphate following transfer is quite far from carbon-3 of the enolate, and a conformational change is required to place the two carbons near each other. The most parsimonious way to accomplish this is to have an enzyme base deprotonate the carboxyl group of carboxyphosphate, after which carboxyphosphate decomposes to form enzyme-bound $\mathrm{CO}_{2}$ and Pi. Earlier mechanisms (87) did not recognize this aspect. This step brings $\mathrm{CO}_{2}$ above the plane of the enolate and within bonding distance of its carbon-3. $\mathrm{CO}_{2}$ in this intermediate is sequestered so that under optimum catalytic conditions it seldom escapes [3\% (6)], but under other circumstances $\mathrm{CO}_{2}$ is lost easily, as when the metal ion is changed in such a way as to lower the reactivity of the enolate. In the case of a variety of PEP analogs, loss of $\mathrm{CO}_{2}$ competes effectively with carboxylation (cf Table 1). In some cases, the formation of enzyme-bound $\mathrm{CO}_{2}$ must be reversible. Isotope exchange studies on (Z)-3-methyl-PEP $(29,86)$ and 3-fluoro-PEP (50) require that $\mathrm{CO}_{2}$ is formed reversibly and can scramble isotopes and return to starting material. It is not clear whether $\mathrm{CO}_{2}$ formation is reversible in the case of PEP. Isotope-effect results suggest that it is not. 
$1 *$

MASERHHSIDAQLRALAPGKVSEELIQYDALLVDRFLDILODLHGPSLREFVQECYEVSADYEGKKDTSKLGELG

76.

AKLTGLAPADAILVASSILHMLNLANLAEEVELAHRRRNSKLKHGDFSDEGSATTESDIEETLKRLVSLGKTPAE

151

VFEALKNOSVDLVFTAHPTOSARRSLLOKNARIRNCLTQLSAKDVTVEDKKELDEALHREIOAAFRTDEIRRAOP

226

TPQDEMRYGMSYIHETVWNGVPKFLRRVDTALKNIGINERLPYDVPLIKFCSWMGGDRDGNPRVTPEVTRDVCLL

3012

SRMMAANLYINQVEDLMFELSMWRCNDELRARAEEVOSTPASKKVTKYYIEFWKOIPPNEPYRVILGAVRDKLYN

$376 \quad 3 \quad 45$

TRERARHLLATGFSEISEDAVFTKIEEFLEPLELCYKSLCECGDKAIADGSLLDLLROVFTFGLSLVKLDIROES

451

EROTDVIDAITTHLGIGSYRSWPEDKRMEWLVSELKGKRPLLPPDLPMTEEIADVIGAMRVLAELPIDSFGPYII

526

SMCTAPSDVLAVELLQREMWHSPAVPVVPLFERLADLQAAPASVEKLFSTDWYINHINGKOOVMVGYSDSGKDAG

601

RLSAAWQLYVAQEEMAKVAKKYGVKLTLFHGRGGTVGRGGGPTHLAILSOPPDTINGSIRVTVOGEVIEFMFGEE

676

NLCFOSLORFTAATLEHGMHPPVSPKPEWRKLMEEMAVVATEEYRSVVVKEPRFVEYFRSATPETEYGKMNIGSR

751

PAKRRPGGGITTLRAIPWIFSWTOTRFHLPVWLGVGAAFKWAIDKDIKNFOKLKEMYNEWPFFRVTLDLLEMVFA

826

KGDPGIAGLYDELLVAEELKPFGKQLRDKYVETQQLLLQIAGHKDILEGDPYLKOGLRLRNPYITTLNVFOAYTL

901

960

KRIRDPSFKVTPOPPLSKEFADENKPAGLVKLNGERVPPGLEDTLILTMKGIAAGMONTG

Figure 1. Deduced amino-acid sequence of the $\mathrm{C}_{4}$-PEPC isoform from Sorghum (67). The plant-invariant phosphorylation domain, with its target Ser $\left(^{*}\right)$, is underlined twice, whereas the species-invariant functional regions identified to date are underlined singly. The specific His, Lys, and Arg residues targeted by site-directed mutagenesis or chemical modification (see text) are indicated within these three domains $(\bullet)$. C (1-5), plant-invariant Cys residues.

In the final chemical step of the overall reaction, $\mathrm{CO}_{2}$ combines with the metal-stabilized enolate. It is interesting to note that there is no evidence that this step is reversible, even though the reverse reaction (decarboxylation of metal-chelated OAA) is well known in other systems. Finally, Pi and OAA are released. 

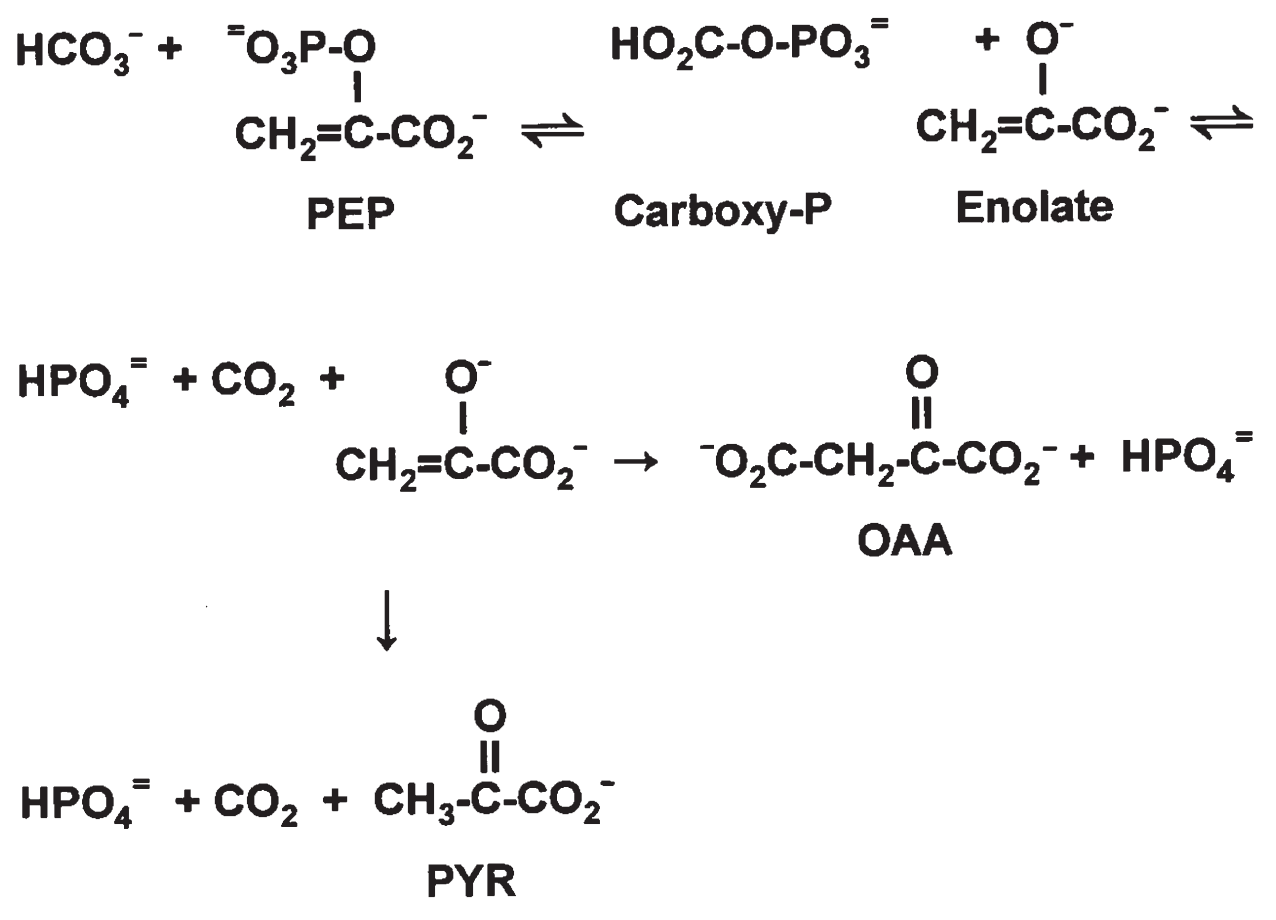

Figure 2. Mechanism of carboxylation and hydrolysis of PEP by PEPC. PYR, pyruvate.

\section{Posttranslational Regulation of PEP-Carboxylase Activity}

It is well documented that the activity of the various isoforms of plant PEPC are subject to allosteric control by a variety of positive [e.g. glucose 6-P (G6P), triose-P] and negative (e.g. L-malate, Asp) metabolite effectors, especially when assayed at suboptimal $\mathrm{pH}$ values that approximate that of the cytosol (e.g. 3, 23, 65, 66, 68, 90, 100, 101, 104). For example, the $K_{i}$ (L-malate) of the intact recombinant $\mathrm{C}_{4}$ enzyme from Sorghum is decreased about 25-fold at pH 7.3 compared with pH 8.0 (23). Although changes in the cytosolic levels of these opposing allosteric effectors and $\mathrm{H}^{+}$likely contribute to the overall regulation of PEPC activity in vivo $(22,26,54,66,90)$, research over the past decade has focused primarily on the reversible phosphorylation of the enzyme. In fact, cytosolic PEPC and sucrose-P synthase presently represent the two best-defined examples of in vivo regulatory enzyme phosphorylation in plants $(40 \mathrm{~A}, 41)$. 


\section{Regulatory Phosphorylation of Photosynthetic PEPC}

The regulatory phosphorylation of photosynthetic PEPC has been intensively studied and recently reviewed $(41,54,68,84,96,117)$ since the initial observations were published about ten years ago on the CAM and $\mathrm{C}_{4}$ isoforms $(10,38,51,80,81,82)$. As an important prelude to these protein-phosphorylation studies, several reports had appeared that indicated that both photosynthetic PEPC isoforms were subject to a striking diel regulation in vivo that altered the enzyme's activity and/or sensitivity to L-malate under near-physiological assay conditions, without accompanying changes in $\mathrm{V}_{\max }$ or PEPC amount (e.g. 42, 60, 81, 125). It thus became evident that the CAM enzyme was upregulated at night and downregulated during the day, thereby paralleling the classical changes in CAM physiology (e.g. leaf atmospheric $\mathrm{CO}_{2}$ fixation and titratable acidity) (66). Related investigations of several CAM plants under continuous night or day conditions indicated that CAM physiology, as well as the L-malate sensitivity of PEPC, was controlled by an endogenous circadian rhythm rather than by light or dark signals per se $(83,125)$. In marked contrast, $\mathrm{C}_{4}$ PEPC was shown to be reversibly light activated in vivo by a mechanism that was dependent, either directly or indirectly, on photosynthesis and modulated by the incident photosynthetic photon flux density above a minimum threshold of about $300 \mu \mathrm{mol} \mathrm{m}^{-2} \mathrm{~s}^{-1}$ $(7,36,55,60,78,98)$.

It is now established unequivocally by a wealth of in vivo and in vitro data that this striking diel regulation is caused by changes in the phosphorylation state of a single serine residue near the $\sim 110-\mathrm{kDa}$ subunit's N-terminus (e.g. Ser-8 and Ser-15 in the Sorghum and maizee $\mathrm{C}_{4}$ enzymes, respectively, and Ser-11 in PEPC from the facultative CAM plant Mesembryanthemum crystallinum) $(9,23,53,58,110,121)$. Upregulation/ phosphorylation of the target enzyme is catalyzed by a highly regulated (see below) protein kinase and downregulation/dephosphorylation by a typical mammalian-type protein phosphatase $2 \mathrm{~A}(7,11,12,12 \mathrm{~A}, 27,52,53,55,56,78)$. It is notable that this target Ser resides in a plant-invariant motif [E/DR/KxxSIDAQL/MR (see Figure 1)] that is absent in the bacterial and cyanobacterial primary structures deduced to date $(67,68,79 \mathrm{~A}, 96 \mathrm{~A}, 114)$. Moreover, in vitro studies with the intact, recombinant Sorghum $\mathrm{C}_{4}$ enzyme have established that phosphorylation of this N-terminal domain not only renders PEPC considerably less sensitive to inhibition by L-malate under near-physiological assay conditions ( $\sim$ sevenfold increase in $K_{i}$ ) but, conversely, both more active and more sensitive to activation by G6P ( fivefold decrease in $\left.K_{a}\right)(23,26)$. Thus, this reversible means of fine tuning the activity and allosteric properties of PEPC is unique to the plant enzyme.

The molecular mechanism by which protein phosphorylation regulates $\mathrm{C}_{4}$ PEPC has recently been addressed by site-directed mutagenesis and 
chemical modification. The introduction of a monoanionic residue at position 8 in the recombinant Sorghum enzyme by directed mutagenesis (S8D) or sequential mutagenesis (S8C) and S-carboxymethylation functionally mimics the specific effects of regulatory phosphorylation on the target enzyme. In contrast, various neutral substitutions (S8T, S8Y, S8C, S-carboxamidomethylated S8C) are without major influence (23, 25, 121; GB Maralihalli, V Pacquit, B Li, JA Jiao, G Sarath, et al, unpublished data). Consequently, addition of negative charge to this N-terminal domain by reversible phosphorylation appears crucial to this regulatory mechanism, but the exact details must await the high-resolution crystal structures of the dephospho and phospho (or S8D) enzyme-forms.

Recent research on the phosphorylation of $\mathrm{C}_{4}$ and CAM PEPC has focused on the physiologically relevant protein kinase and its requisite signal-transduction chain. This work took on special significance with the near-simultaneous discoveries that the $\mathrm{C}_{4}$ and CAM PEPC kinases were both activated reversibly in vivo by some mechanism involving cytosolic protein turnover, thereby resulting in the upregulation of the kinase and, thus, its target enzyme in the light $\left(\mathrm{C}_{4}\right)$ or at night $(\mathrm{CAM})(7,12,27,55,56,78)$. Not only is the CAM kinase activated at night under the control of a circadian rhythm, but it is also coinduced with its protein-substrate during $\mathrm{C}_{3}$ to $\mathrm{CAM}$ switching in the facultative CAM species M. crystallinum (12, 12A, 70). In contrast, the activity state of the type 2A PEPC-phosphatase catalytic subunit appears to be relatively constant during light-dark $\left(\mathrm{C}_{4}\right)$ or day-night (CAM) transitions (12, $56,78)$, further underscoring the critical role of the kinase in the PEPC-phosphorylation cycle.

Following the initial report by Jiao \& Chollet (52), the extremely lowabundance PEPC kinase has been partially purified about 4000 -fold. It is likely to be a monomer of $\sim 37 / 30-\mathrm{kDa}\left(\mathrm{C}_{4}\right)$ or $\sim 39 / 32-\mathrm{kDa}$ (CAM) polypeptides $(69,70,120)$. As isolated, this protein kinase catalyzes neither autophosphorylation nor the phosphorylation of heterologous substrates (e.g. casein, histone III-S, BSA, leaf sucrose-P synthase). Similarly, position-8 Sorghum $\mathrm{C}_{4}$-PEPC mutants (e.g. S8Y, S8D, S8C) are not phosphorylated except for the Thr substitution (70, 120, 121; GB Maralihalli, V Pacquit, B Li, JA Jiao, G Sarath, et al, unpublished data). In contrast, all plant PEPC isoforms examined to date $\left(\mathrm{C}_{4}, \mathrm{CAM}, \mathrm{C}_{3}\right.$-leaf, root nodule) serve as substrates in vitro $(70,119,120)$, but with a distinct preference for the corresponding PEPC kinase (B Li, XQ Zhang \& R Chollet, unpublished data). Considerable effort has been expended to (re)investigate the $\mathrm{Ca}^{2+}$-dependency of this protein $\mathrm{ki}$ nase. It is our view that although a variety of other protein-Ser/Thr kinases, including $\mathrm{C}_{4}$-leaf calmodulin-like domain protein kinase (CDPK) and mammalian protein kinase A, specifically phosphorylate the single target Ser in plant PEPC in vitro $(7,53,69,85,110)$, only the $\mathrm{Ca}^{2+}$-independent, 30 - to 39$\mathrm{kDa}$ PEPC kinase has been shown to be light-dark $\left(\mathrm{C}_{4}\right)$ or day-night (CAM) 
regulated in vivo $(69,70)$. Notably, these differential activity states of the kinase are maintained throughout chromatography on various matrices and even following SDS-PAGE and subsequent renaturation (69; B Li \& R Chollet, unpublished data). Thus, PEPC kinase is likely up/downregulated in vivo by some mechanism that modulates its amount $(7,12,56,69)$ or else by covalent modification rather than by some noncovalent means (e.g. regulatory subunit, tight-binding effector). Repeated attempts to demonstrate an effect of in vitro dephosphorylation by alkaline phosphatase on the activity states of the light (active) and dark (inactive) $\mathrm{C}_{4}$ kinase and its component 37/30-kDa polypeptides have proven unsuccessful (B Li \& R Chollet, unpublished data).

The signal-transduction chains that impinge upon the highly regulated PEPC kinases are also a focus of current research. Initial studies using a chemical inhibitor-based approach with detached leaves $(7,12,55,56,69,78)$ have been supplanted by in situ analyses with isolated $C_{4}$ mesophyll cells and protoplasts and cell biology techniques $(24 \mathrm{~A}, 30 \mathrm{~A}, 94,117)$. It is now established that the light-induced $\mathrm{C}_{4}$ transduction cascade is initiated in the illuminated chloroplast by photosynthesis and likely involves some "signal" from the light-activated Calvin cycle in the neighboring bundle sheath, possibly 3-P-glycerate (Figure 3). In addition, there is mounting in situ evidence for the involvement of increases in mesophyll-cytosol $\mathrm{pH}$ and $\left[\mathrm{Ca}^{2+}\right]$, the latter perhaps modulating an upstream protein kinase $(24 \mathrm{~A}, 30 \mathrm{~A}, 94,117)$, together with the inhibitor-based data that implicate a key role for a cytosolic protein-synthesis event $(7,8,30 \mathrm{~A}, 56,69,94)$. In contrast, not much is known about the CAM PEPC kinase signal-transduction pathway other than its light independency and the involvement of a circadian rhythm and cytosolic protein turnover (Figure 3) (12, 12A, 83, 84). Clearly, this area would benefit from detailed in situ analyses of intact mesophyll protoplasts isolated from night and day leaves performing CAM.

Finally, the results from leaf $\mathrm{CO}_{2}$-exchange studies have underscored the impact of the PEPC regulatory-phosphorylation cycle on $\mathrm{C}_{4}$ photosynthesis and dark $\mathrm{CO}_{2}$ fixation during $\mathrm{CAM}(8,12,12 \mathrm{~A})$. For example, when the activity states of PEPC kinase and, thus, its target enzyme were downregulated in vivo by short-term pretreatment with cytosolic protein-synthesis inhibitors in the light $\left(C_{4}\right)$ or prior to the night period (CAM), net leaf $\mathrm{CO}_{2}$ uptake was diminished markedly. In contrast, no effects were observed on the activation states of other nuclear-encoded, photosynthesis-related enzymes, stomatal conductance, or $\mathrm{CO}_{2}$ uptake by a $\mathrm{C}_{3}$ leaf $(7,8,56)$. Thus, the phosphorylation of photosynthetic PEPC is a cardinal regulatory event that influences atmospheric $\mathrm{CO}_{2}$ fixation; this mechanism enables this primary carboxylase to function in the leaf cytosol even in the presence of the millimolar levels of $\mathrm{C}_{4}$ acids (e.g. L-malate) required for $\mathrm{C}_{4}$ photosynthesis and CAM. 


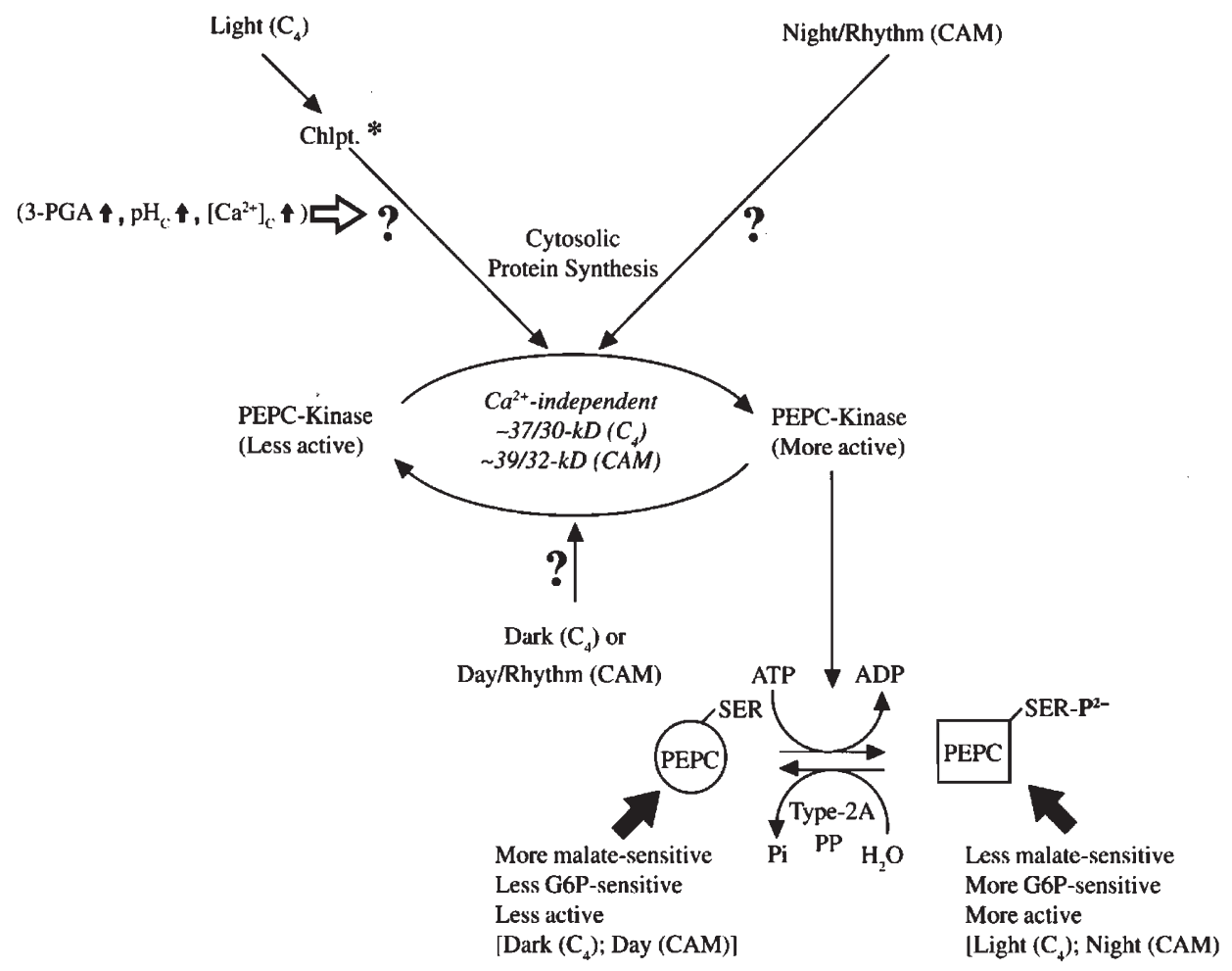

Figure 3. Proposed molecular mechanism for the light-dark $\left(\mathrm{C}_{4}\right)$ or night-day (CAM) regulation of the effector sensitivity [L-malate (negative), G6P (positive)] and activity of photosynthetic PEPC in the leaf mesophyll cell by reversible phosphorylation of a single target serine near the subunit's N-terminus [e.g. Ser-8 in Sorghum (see Figure 1)]. Chlpt. ", illuminated chloroplast; $\mathrm{pH}_{\mathrm{c}}$ and $\left[\mathrm{Ca}^{2+}\right]_{\mathrm{c}^{\prime}}$ mesophyll cytosolic $\mathrm{pH}$ and $\left[\mathrm{Ca}^{2+}\right]$, respectively; 3-PGA, 3-P-glycerate; PP, protein phosphatase. [Updated from Jiao \& Chollet (54).]

\section{Regulatory Phosphorylation of Nonphotosynthetic PEPC Isoforms}

There is now convincing evidence that the reversible phosphorylation of the N-terminal domain of plant PEPC is widespread, if not ubiquitous. In vivo studies with ${ }^{32} \mathrm{Pi}$ have demonstrated the reversible phosphorylation of nonphotosynthetic PEPC in soybean root nodules (136) and in wheat leaves excised from $\mathrm{N}$-deficient seedlings $(24,116)$. Complementary measurements of in vivo changes in PEPC activity and/or malate sensitivity under nearphysiological assay conditions (i.e. low $\mathrm{pH}$, low [PEP] relative to $K_{\mathrm{m}}$ ) have underscored the regulatory nature of this covalent modification in nodules (136), illuminated $\mathrm{C}_{3}$ leaves $(24,116$; B Li, XQ Zhang \& R Chollet, unpublished data), and Vicia faba guard cells microdissected from opening stomata 
(135). Furthermore, related in vitro studies have established that PEPC kinase activity is present in soybean and alfalfa root nodules $(102,115)$, wheat and tobacco leaves $(24,119)$, and Sorghum roots $(91)$, and have demonstrated this kinase's similarity to the $\mathrm{C}_{4}$ and CAM enzymes with respect to its $\mathrm{Ca}^{2+}$ independency, chromatographic properties, and catalytic subunit(s) (24, 91, 119). The activity state of this PEPC kinase is modulated reversibly in vivo by a complex interaction between photosynthesis and $\mathrm{N}\left(\mathrm{C}_{3}\right.$ leaves) or photosynthate supply to $\mathrm{N}_{2}$-fixing root nodules (24; B Li, XQ Zhang \& R Chollet, unpublished data). Thus, the phosphorylation of cytosolic PEPC by a highly regulated protein-Ser/Thr kinase is likely the major posttranslational mechanism for altering the allosteric properties and activity of this "multifaceted" plant enzyme in vivo.

\section{Other Proposed Regulatory Mechanisms}

Two other mechanisms have been proposed for the diel regulation of $\mathrm{C}_{4}$ and CAM PEPC activity and/or sensitivity to L-malate based wholly on in vitro observations.

Dimer-Tetramer Interconversion - The Wedding laboratory found that CAM PEPC purified from day- and night-adapted Crassula argentea leaves exists as kinetically distinct but interconvertible oligomers (128). The day enzyme was mainly a malate-sensitive homodimer $\left(\mathrm{a}_{2}\right)$ and the night form a malate"insensitive" homotetramer $\left(a_{4}\right)$, with about a twofold higher $K_{i}$. PEP, G6P, $\mathrm{Mg}^{2+}$, or a higher [PEPC] favors conversion of $\mathrm{a}_{2}$ to $\mathrm{a}_{4}$, whereas L-malate or a lower [PEPC] shifts the equilibrium toward the dimeric form $(79,128$, 129). Similar in vitro association/dissociation properties have been reported for the active $C_{4}$ homotetramer from maize $(123,127)$. There is no evidence, however, to support the involvement of these aggregation-state changes in the diel regulation of the CAM and $\mathrm{C}_{4}$ isoforms in vivo. On the contrary, several reports document that the phospho and dephospho $\mathrm{C}_{4}$ and $\mathrm{CAM}$ enzyme forms are isolated in the same aggregation state while retaining the characteristic differential sensitivity to L-malate $(4,63,77,82,122)$. Thus, it is our opinion that there is not a significant regulation of photosynthetic PEPC in vivo by changes in its aggregation state.

Redox Regulation - Even more speculative in our view is the proposal that the regulation of cytosolic $\mathrm{C}_{4}$ PEPC may be primarily under the control of the redox state of certain critical cysteines $(13,45)$. While there are, indeed, five plant-invariant Cys residues in the various PEPC isoforms that are absent in the microbial enzymes (Figure 1) $(67,68,79 \mathrm{~A}, 114)$, none of them have been shown specifically to be involved in regulation of activity or L-malate sensitivity. On the contrary, related observations with the dephospho maize 
enzyme indicate no effect of reduced cytosolic thioredoxin $h$ on the properties of $\mathrm{C}_{4}$ PEPC in vitro (52).

\section{PEPC Gene Structure, Expression, and Molecular Evolution}

\section{Multigene Families}

PEPC isoforms have been characterized in both photosynthetic and nonphotosynthetic tissues of various plants (reviewed in 68, 114). Consistent with the enzyme's functional diversity, small multigene families have been found. For example, three PEPC nuclear genes - SvC3, SvC3RI, and SvC4 - have been characterized in Sorghum that encode the $\mathrm{C}_{3}$-like housekeeping and root forms and the $\mathrm{C}_{4}$-photosynthetic isoform, respectively (67). The maize family possesses at least five genes (37) that can be classified into three distinct groups (99). The $\mathrm{C}_{4}$-PEPC gene is unique and is located near the centromere of chromosome 9. Three other genes have been mapped to different loci on chromosomes $4 \mathrm{~L}, 5$, and $7(37,47,61)$. Both $C_{3}$ and $C_{4}$ species in the dicot genus Flaveria contain very similar families of distinct $P p c$ subgroups $(40,95)$. The $C_{4}$ isoform in Flaveria trinervia is encoded by the PpcA subgroup of the family. Homologous PpcA genes are found in the $C_{3}$ species Flaveria pringlei; however, they are weakly expressed, and their transcripts do not show the strict leaf-specific accumulation pattern found in the related $C_{4}$ species (40). In the facultative CAM plant $M$. crystallinum, two isogenes (Ppc1, Ppc2) have been described, and another distinct member might exist $(17,18)$; the transcriptional activity of $P p c 1$ is strongly and selectively enhanced during $\mathrm{C}_{3}$ to CAM switching induced by salt stress (18). The Brassica napus genome contains more than four highly similar PEPC genes, but some of them lack specific introns (133). PEPC gene families have also been found or suggested to exist in sugarcane, Amaranthus, tobacco, alfalfa, rice, wheat (reviewed in 68), and Arabidopsis (79B).

\section{Ppc and PEPC Sequence Comparisons}

The plant PEPC genes contain nine introns (with the exception reported in 133) of variable length but identical location with respect to the coding regions. Consensus intron/exon splice sites (aGGTaag - tgcAGg) are conserved. Generally, a classical gene organization is observed, although in some $\mathrm{C}_{4}$ - and $\mathrm{C}_{3}$-type $P p c$ genes there is no typical TATA box, and multiple polyadenylation sites are found in the $3^{\prime}$-untranslated region $(15,43,74,132)$.

In alignments of all the deduced PEPC amino acid sequences reported, several highly conserved residues and motifs are found, and these likely contribute to the domains involved in the active site and/or regulation of the enzyme (see sections on Active-Site Structure and Regulatory Phosphorylation) 
$(67,68,79 \mathrm{~A}, 96 \mathrm{~A}, 114)$. Figure 1 exemplifies these structural features in the deduced sequence of the $\mathrm{C}_{4}$-isoform from Sorghum (SvC4). The phosphorylation motif near the N-terminus (E/DR/KxxSIDAQL/MR), including the target Ser, and five cysteine residues, some of which have been proposed to be involved in redox regulation and/or stabilization of the tetrameric structure of the holoenzyme $(13,45)$, are specific to plant PEPC $(68,79 \mathrm{~A}, 114)$. In addition, there are several species-invariant motifs in all PEPCs examined to date (TAHPT, VMxGYSDSxKDxG, FHGRGxxxxRGxxP) that contain specific His, Lys, and Arg residues implicated in the active-site domain (see section on Active-Site Structure; 3, 57, 79A, 96, 96A, 112). In general, the C-terminal half of the $\sim 110-k D a$ PEPC polypeptide contains most of these presumed active-site determinants, whereas the N-terminal half appears to include the motifs that are regulatory in nature $(53,57,110,114)$. Further insight into the structure/ function relationships of PEPC must await continued mutagenesis of these and other (114) highly conserved domains and, most importantly, high-resolution crystallographic analysis of the plant and microbial proteins.

\section{Ppc Promoter Analysis and Transcription}

The $\mathrm{C}_{4}$-PEPC gene is expressed in photosynthetic tissues during greening via a phytochrome-mediated response (113). Expression of this gene is not necessarily coupled to the development of Kranz leaf anatomy because, in maize, it also occurs in such tissues as the inner leaf sheaths and tassels (43). In addition to light, cytokinins upregulate the transcriptional activity of the $\mathrm{C}_{4}$-PEPC gene in maize leaves recovering from $\mathrm{N}$ deficiency (106), whereas in Sorghum abscisic acid (ABA) stimulates specific Ppc mRNA accumulation (2). In M. crystallinum, CAM-PEPC gene expression is induced by salt stress and/or ABA during $\mathrm{C}_{3}$ to CAM switching, and these effects are moderated by light (76). In the CAM plant Kalanchoë blossfeldiana, changes in photoperiod and $\mathrm{ABA}$ are also involved in the induction of the photosynthetic PEPC gene (108). Lastly, $\mathrm{C}_{3}$-type PEPC mRNAs are accumulated during the development of alfalfa root nodules $(92,115)$ and in recovering roots of N-deficient Sorghum (P Gadal, L Lepiniec \& S Santi, unpublished data).

Light-responsive elements corresponding to those in the nuclear genes encoding the small subunit of Rubisco are lacking in the $\mathrm{C}_{4}-P p c$ promoters of maize and Sorghum. Other conserved, direct repeated sequences (TTACCACTAGCTA), or the light-responsive element (CCTTATCCT) characterized previously in the promoter of light-inducible phytochrome genes, could play such a role, at least in part $(15,68,74)$. The maize nuclear factor (MNF) (see below; 131) and SV40 Sp1 $(15,68,74)$ binding sites - (AAGG) and (CCGCCC), respectively - are also found in $\mathrm{C}_{4}-P p c$ promoters. In addition, the presence of CpG islands (68) is consistent with the possible regulation of specific sites in 
the promoters of both $\mathrm{C}_{4}$ and $\mathrm{C}_{3}$ PEPC genes by changes in DNA methylation status (64). In the Sorghum SvC3 and SvC3RI Ppc promoters, sequences homologous to the light-responsive element AT-1 (AATATTTTTATA) and nod(TCTACGTAGA) and G-boxes (CCACGTGG) are found (68). Both $\mathrm{C}_{4}$ and $\mathrm{C}_{3}$ species of Flaveria have orthologous $\mathrm{C}_{4}$ genes ( $P p c A$ subgroup), the 5'-flanking regions of which are essentially homologous and share CCAAT, AT- 1 , and GT-1 III/IIIa boxes and an octameric motif known to confer cell-type specificity (40). It has been suggested that certain specific features of the $\mathrm{C}_{4}$-PEPC gene promoter in F. trinervia could account for the much higher expression level in this $\mathrm{C}_{4}$ species, including a light-responsive box II element, the microheterogeneity of the sequence around the TATA box, and the presence of a putative scaffold attachment region near the promoter that is often associated with highly expressed genes (40). Recent experiments using transgenic tobacco plants have shown that the sequences responsible for the enhanced, leaf-specific expression of $\mathrm{C}_{4} P p c$ in $F$. trinervia are located between positions -2118 and -500 relative to the transcription start site in the PpcA promoter (105); whether these sequences involve the above-mentioned proximal elements is not known.

Three leaf-specific DNA-binding proteins (MNF1, MNF2a, MNF2b) have been shown to interact specifically with the promoter of the maize $\mathrm{C}_{4}$-PEPC gene $(130,131)$. Among these nuclear factors, MNF2a is presumed to act as a negative transcriptional effector (130). Two cDNA clones (MNB1a, MNB1b) encoding proteins that bind to an AAGG motif at the MNF1 site have been identified (131). Two other clones (designated 281, 282) may encode PEP1, a light-dependent factor interacting with the promoter of the maize $\mathrm{C}_{4}$-PEPC gene (59). In M. crystallinum, salt stress causes three protein factors (PCAT-1, 2, and -3) to differentially recognize two AT-rich regions in the Ppc1 promoter (16). Recently, several salt-responsive enhancer regions and one silencer region have been identified in this promoter (98A).

From the above, it is clear that data on nuclear trans-acting factors and the corresponding regulatory cis-acting DNA sequences of the Ppc promoters are still relatively scarce. Thus, no clear picture has emerged concerning the regulatory mechanisms that control the transcription rate of the different classes of PEPC genes in plants.

\section{Transgenic Plants}

In transgenic tobacco transformed with maize $\mathrm{C}_{4}-P p c 1$ genes containing the upstream regulatory region (about $2 \mathrm{~kb}$ ), a low level of PEPC transcripts was produced; although their size was aberrantly large, accumulation still required light (44). These transformants possessed a twofold increase in PEPC activity that was correlated with the appearance of a high- $K_{\mathrm{m}}(\mathrm{PEP}) \mathrm{C}_{4}$ form of the enzyme and an elevated level of leaf malate. However, these biochemical 
changes did not result in any detectable physiological effects with respect to the rate of leaf net photosynthesis in air and to the $\mathrm{CO}_{2}$ compensation concentration. In a related study, the maize $\mathrm{C}_{4}$-PEPC gene was placed under the control of a CaMV 35S promoter (62). Although the transgenic tobacco plants contained Ppc transcripts of the correct size and about twice as much PEPC protein, their growth rate was retarded relative to that of the nontransformed plants. Transgenic tobacco plants transformed with either the $\mathrm{C}_{4}$-PEPC gene from Sorghum or chimeric constructs containing the promoter of the $\mathrm{C}_{4}$ gene from maize fused to the gusA reporter gene showed a high expression of transcripts as well as leaf mesophyll-cell specificity $(75,107)$. Similar results have been reported recently in transgenic rice using the same experimental strategy (73). Transgenic tobacco plants also expressed constructs containing various parts of the 5'-flanking region of the PpcA1 ( $\mathrm{C}_{4}$-type) genes from both $\mathrm{C}_{4}$ and $\mathrm{C}_{3}$ species of Flaveria (105). In this heterologous system, only the $\mathrm{C}_{4}-\mathrm{Ppc}$ promoter from the $\mathrm{C}_{4}$ species conferred a high level of reporter gene expression, thus showing that it contains regulatory cis-elements responsible for abundant expression. In addition, a leaf palisade mesophyll-cell specificity was partially maintained in these transgenic tobacco plants. Hence, it appears that most of the regulatory elements that control the light-inducible expression of $P p c$ in $\mathrm{C}_{4}$ leaves are also present in $\mathrm{C}_{3}$ plants. On the other hand, although the CAMspecific Ppc promoter from the $M$. crystallinum gene is highly active in transgenic tobacco, it directs transcript synthesis in most cell types and lacks the salt inducibility found in its natural cellular environment (17). Finally, in homologous transient-expression systems using leaf-, stem-, and root-derived protoplasts from maize, a cell-specific expression pattern is largely dependent on the specific Ppc promoter used (99). In this system, transcript accumulation is not immediate but rather is related to light-dependent developmental changes, in contrast with other photosynthetic genes. This latter observation has led to the suggestion that distinct transduction pathways operate for the coordination of light-dependent genes encoding photosynthetic enzymes (99).

\section{Molecular Evolution}

Phylogenetic trees have been constructed using unambiguously aligned sites from the available PEPC amino acid sequences as well as on the basis of parsimony or distance analyses $(1,47,61,67,68,114)$. The cyanobacterial and bacterial PEPCs consistently group with prokaryotic phylogenetic relationships (68). As for the plant enzymes, phylogenetic relationships have been studied with particular emphasis on the molecular mechanisms that have shaped the expression characteristics and kinetic properties of PEPC during the evolutionary transition from $\mathrm{C}_{3}$ into $\mathrm{CAM}$ and $\mathrm{C}_{4}$ plants. The acquisition of these new photosynthetic strategies by a wide variety of plant species indicates that they have originated independently and on many 
separate occasions during the evolution of flowering plants, with CAM being the antecedent of $C_{4}(47,61,67)$. Thus, an obvious question is how to account for the polyphyletic evolution of $\mathrm{C}_{4}$ plants. From the various independently derived trees it can be inferred that all plant PEPC sequences diverged from a single common ancestral gene. On the other hand, the presence of different genes could have preceded angiosperm diversification and perhaps also that of higher plants. $\mathrm{C}_{4}$-PEPC genes could have arisen from a duplication event long before the monocot-dicot divergence and thus prior

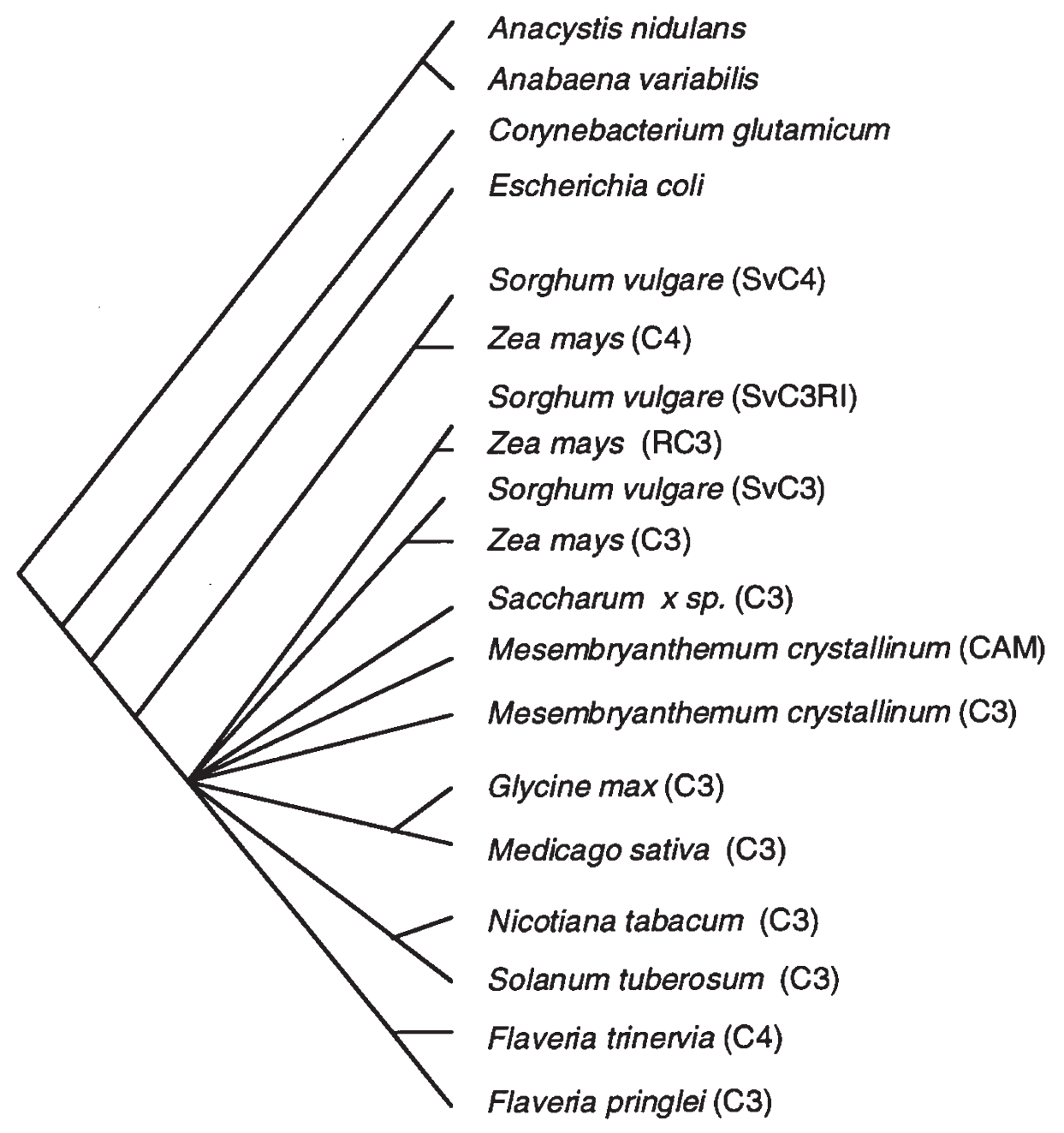

Figure 4 Consensus phylogenetic tree of 19 microbial and plant PEPCs. Branch lengths have no significance (see 67, 68 for details). SvC4, SvC3RI, and SvC3 are the photosynthetic, root, and housekeeping isoforms of Sorghum vulgare PEPC, respectively; Zea mays C4, RC3, and C3 are the corresponding isoforms in maize. (Redrawn from Lepiniec et al (68), with permission from Elsevier Science Ireland Ltd.) 
to the appearance of $\mathrm{C}_{4}$ plants. In this manner, the PEPC gene for $\mathrm{C}_{4}$ photosynthesis could have evolved in a limited number of species while disappearing in others $(47,61,67)$. In the consensus tree depicted in Figure 4, $\mathrm{C}_{4}$-PEPCs from the monocots Sorghum and maize are clearly distinguishable from the various $C_{3}$ and CAM isoforms and also from their indigenous $C_{3}$ counterparts (e.g. SvC3RI, SvC3). In contrast, the photosynthetic enzyme in the $\mathrm{C}_{4}$-dicot $F$. trinervia is more closely related to the various isoforms in $\mathrm{C}_{3}$ and CAM dicots $(40,95)$ than to the two monocot $C_{4}$-PEPCs (68). Furthermore, because the promoters of the $\mathrm{C}_{4}$-PEPC gene in $F$. trinervia and the orthologous gene in F. pringlei $\left(\mathrm{C}_{3}\right)$ are very similar, it has been suggested that a $\mathrm{C}_{3}$ promoter could have been "tuned" to meet the special demands of $\mathrm{C}_{4}$ photosynthesis (40). The possibility that an alternative evolution has led to the formation of $\mathrm{C}_{4}$ enzymes in the various genera containing $\mathrm{C}_{4}$ species could account for the observed divergence between monocots and dicots (40). Finally, it is not clear why a homologous form of $\mathrm{C}_{4}$-PEPC is not found in dicots because, as mentioned above, a primordial PEPC form could have arisen before the divergence of monocots and dicots (68). Further investigations involving PEPC sequences from different genera are required to refine the phylogenetic relationships of the microbial and plant enzymes, including sequence analysis of green algal PEPCs and additional gymnosperm species (Picea abies) (96A).

\section{Conclusions and Future Prospects}

While the past decade has seen a number of truly impressive revelations concerning PEPC, future research awaits the results of three-dimensional structure studies that will provide another important chapter in PEPC mechanism, regulation, allosteric effects, and other areas. In addition, the emerging pictures of the highly regulated PEPC kinase, together with its requisite signal-transduction cascades, must be completed. Related work on the heteromeric intracellular form of the type 2A protein phosphatase that dephosphorylates plant PEPC in the cytosol will also be important (cf 122A). With the recent generation of the first $\mathrm{C}_{4}$ PEPC-deficient mutant in the dicot Amaranthus edulis (20) and the development of an efficient, Agrobacteriummediated transformation system for $\mathrm{C}_{4}$ dicots (14), the stage is finally set for the genetic manipulation of $C_{4}$ photosynthesis in vivo by engineering the regulatory properties and amount of PEPC in the leaf cytosol. We anticipate that these and other fertile avenues for future research on PEPC will continue to deepen our understanding of this "multifaceted" enzyme in plants. Finally, we hope that this survey has reminded the reader that there is, indeed, another $\mathrm{CO}_{2}$-fixing enzyme in plants besides Rubisco that is worthy of detailed study. 


\section{Acknowledgments}

R. C. gratefully acknowledges the continued support of his laboratory's research on plant PEPC by NSF, USDA/NRI, and the Nebraska Agricultural Research Division (in which this article is published as Journal Series No. 11, 284).

\section{Literature Cited}

1. Albert HA, Martin T, Sun SSM. 1992. Structure and expression of a sugarcane gene encoding a housekeeping phosphoenolpyruvate carboxylase. Plant Mol. Biol. 20:663-71

2. Amzallag GN, Lerner HR, Poljakoff-Mayber A. 1990. Exogenous ABA as a modulator of the response of Sorghum to high salinity. J. Exp. Bot. 41:1529-34

3. Andreo CS, González DH, Iglesias AA. 1987. Higher plant Phosphoenolpyruvate carboxylase: structure and regulation. FEBS Lett. 213:1-8

4. Arrio-Dupont M, Bakrim N, Echevarria C, Gadal P, Le Maréchal P, Vidal J. 1992. Compared properties of phosphoenolpyruvate carboxylase from dark- and light-adapted Sorghum leaves: use of a rapid purification technique by immunochromatography. Plant Sci. 81:37-46

5. Ausenhus SL. 1993. Phosphoenolpyruvate carboxylase from maize: function of the divalent metal ion in binding and catalysis. PhD thesis. Univ. Wis., Madison. 160 pp.

6. Ausenhus SL, O'Leary MH. 1992. Hydrolysis of phosphoenolpyruvate catalyzed by phosphoenolpyruvate carboxylase from Zea mays. Biochemistry 31:6427-31

7. Bakrim N, Echevarria C, Crétin C, Arrio-Dupont M, Pierre JN, et al. 1992. Regulatory phosphorylation of Sorghum leaf Phosphoenolpyruvate carboxylase: identification of the protein-serine kinase and some elements of the signal-transduction cascade. Eur. J. Biochem. 204:821-30

8. Bakrim N, Prioul JL, Deleens E, Rocher JP, Arrio-Dupont M, et al. 1993. Regulatory phosphorylation of $\mathrm{C}_{4}$ Phosphoenolpyruvate carboxylase: a cardinal event influencing the photosynthesis rate in Sorghum and maize. Plant Physiol. 101:891-97

9. Baur B, Dietz KJ, Winter K. 1992. Regulatory protein phosphorylation of Phosphoenolpyruvate carboxylase in the facultative crassulacean-acid-metabolism plant Mesembryanthemum crystallinum L. Eur. J. Biochem. 209:95-101

10. Budde RJA, Chollet R. 1986. In vitro phosphorylation of maize leaf phosphoenolpyruvate carboxylase. Plant Physiol. 82:1107-14

11. Carter PJ, Nimmo HG, Fewson CA, Wilkins MB. 1990. Bryophyllum fedtschenkoi protein phosphatase type 2A can dephosphorylate phosphoenolpyruvate carboxylase. FEBS Lett. 263:233-36

12. Carter PJ, Nimmo HG, Fewson CA, Wilkins MB. 1991. Circadian rhythms in the activity of a plant protein kinase. EMBO J. 10:2063-68

12A. Carter PJ, Wilkins MB, Nimmo HG, Fewson CA. 1995. Effects of temperature on the activity of phosphoenolpyruvate carboxylase and on the control of $\mathrm{CO}_{2}$ fixation in Bryophyllum fedtschenkoi. Planta 196:375-80

13. Chardot TP, Wedding RT. 1992. Role of cysteine in activation and allosteric regulation of maize Phosphoenolpyruvate carboxylase. Plant Physiol. 98:780-83

14. Chitty JA, Furbank RT, Marshall JS, Chen Z, Taylor WC. 1994. Genetic transformation of the $\mathrm{C}_{4}$ plant, Flaveria bidentis. Plant J. 6:949-56

15. Crétin C, Santi S, Keryer E, Lepiniec L, Tagu D, et al. 1991. The phosphoenolpyruvate carboxylase gene family of Sorghum: promoter structures, amino acid sequences and expression of genes. Gene 99:87-94

16. Cushman JC, Bohnert HJ. 1992. Salt stress alters A/T-rich DNA-binding factor interactions within the phosphoenolpyruvate carboxylase promoter from Mesembryanthemum crystallinum. Plant Mol. Biol. 20:411-24

17. Cushman JC, Meiners MS, Bohnert HJ. 1993. Expression of a phosphoenolpyruvate carboxylase 
promoter from Mesembryanthemum crystallinum is not salt-inducible in mature transgenic tobacco. Plant Mol. Biol. 21:561-66

18. Cushman JC, Meyer G, Michalowski CB, Schmitt JM, Bohnert HJ. 1989. Salt stress leads to differential expression of two isogenes of phosphoenolpyruvate carboxylase during Crassulacean acid metabolism induction in the common ice plant. Plant Cell 1:715-25

19. Deroche ME, Carrayol E. 1988. Nodule phosphoenolpyruvate carboxylase: a review. Physiol. Plant. 74:775-82

20. Dever LV, Blackwell RD, Fullwood NJ, Lacuesta M, Leegood RC, et al. 1995. The isolation and characterization of mutants of the $\mathrm{C}_{4}$ photosynthetic pathway. J. Exp. Bot. 46:1363-76

21. Díaz E, O'Laughlin JT, O'Leary MH. 1988. Reaction of phosphoenolpyruvate carboxylase with (Z)3-bromophosphoenolpyruvate and (Z)-3-fluorophosphoenolpyruvate. Biochemistry 27:1336-41

22. Doncaster HD, Leegood RC. 1987. Regulation of phosphoenolpyruvate carboxylase activity in maize leaves. Plant Physiol. 84:82-87

23. Duff SMG, Andreo CS, Pacquit V, Lepiniec L, Sarath G, et al. 1995. Kinetic analysis of the nonphosphorylated, in vitro phosphorylated, and phosphorylation-site-mutant (Asp8) forms of intact recombinant $C_{4}$ Phosphoenolpyruvate carboxylase from sorghum. Eur. J. Biochem. 228:92-95

24. Duff SMG, Chollet R. 1995. In vivo regulation of wheat-leaf Phosphoenolpyruvate carboxylase by reversible phosphorylation. Plant Physiol. 107:775-82

24A. Duff SMG, Giglioli-Guivarc'h N, Pierre J-N, Vidal J, Condon SA, Chollet R. 1996. In situ evidence for the involvement of calcium and bundle sheath-derived photosynthetic metabolites in the $\mathrm{C}_{4}$ Phosphoenolpyruvate-carboxylase kinase signal-transduction chain. Planta. In press

25. Duff SMG, Lepiniec L, Crétin C, Andreo CS, Condon SA, et al. 1993. An engineered change in the l-malate sensitivity of a site-directed mutant of sorghum Phosphoenolpyruvate carboxylase: the effect of sequential mutagenesis and S-carboxymethylation at position 8. Arch. Biochem. Biophys. 306:272-76

26. Echevarria C, Pacquit V, Bakrim N, Osuna L, Delgado B, et al. 1994. The effect of pH on the covalent and metabolic control of $\mathrm{C}_{4}$ Phosphoenolpyruvate carboxylase from Sorghum leaf. Arch. Biochem. Biophys. 315:425-30

27. Echevarría C, Vidal J, Jiao JA, Chollet R. 1990. Reversible light activation of the Phosphoenolpyruvate carboxylase protein-serine kinase in maize leaves. FEBS Lett. 275:25-28

28. Farquhar GD, Ehleringer JR, Hubick KT. 1989. Carbon isotope discrimination and photosynthesis. Annu. Rev. Plant Physiol. Plant Mol. Biol. 40:503-37

29. Fujita N, Izui K, Nishino T, Katsuki H. 1984. Reaction mechanism of phosphoenolpyruvate carboxylase: bicarbonate-dependent dephosphorylation of phospho enol-a-ketobutyrate. Biochemistry 23:1774-79

30. Gawlita E, Caldwell WS, O'Leary MH, Paneth P, Anderson VE. 1995. Kinetic isotope effects on substrate association: reactions of phosphoenolpyruvate with phosphoenolpyruvate carboxylase and pyruvate kinase. Biochemistry 32:2577-83

30A. Giglioli-Guivarc'h N, Pierre J-N, Brown S, Chollet R, Vidal J, Gadal P. 1996. The light-dependent transduction pathway controlling the regulatory phosphorylation of $\mathrm{C}_{4}$ Phosphoenolpyruvate carboxylase in protoplasts from Digitaria sanguinalis. Plant Cell 8:In press

31. González DH, Andreo CS. 1986. Phospho enolpyruvate carboxylase from maize leaves: studies using $\beta$-methylated phosphoenolpyruvate analogues as inhibitors and substrates. Z. Naturforsch. 41C:1004-10

32. González DH, Andreo CS. 1988. Carboxylation and dephosphorylation of phosphoenol-3-fluoropyruvate by maize leaf phosphoenolpyruvate carboxylase. Biochem. J. 253:217-22

33. González DH, Andreo CS. 1988. Identification of 2-enolbutyrate as the product of the reaction of maize leaf phosphoenolpyruvate carboxylase with (Z)- and (E)-2-phosphoenolbutyrate: evidence from NMR and kinetic measurements. Biochemistry 27:177-83

34. Gonzalez DH, Andreo CS. 1988. Stereoselectivity of the interaction of E- and Z-2-Phosphoenolbutyrate with maize leaf Phosphoenolpyruvate carboxylase. Eur. J. Biochem. 173:339-43

35. González DH, Andreo CS. 1989. The use of substrate analogues to study the active-site structure and mechanism of PEP carboxylase. Trends Biochem. Sci. 14:24-27 
36. Grammatikopoulos G, Manetas Y. 1990. Diurnal changes in phosphoenolpyruvate carboxylase and pyruvate, orthophosphate dikinase properties in the natural environment: interplay of light and temperature in $\mathrm{a}_{4}$ thermophile. Physiol. Plant. 80:593-97

37. Grula JW, Hudspeth RL. 1987. The phosphoenolpyruvate carboxylase gene family of maize. In Plant Gene Systems and Their Biology, ed. JL Key, L McIntosh, pp. 207-16. New York: Liss

38. Guidici-Orticoni MT, Vidal J, Le Maréchal P, Thomas M, Gadal P, Rémy R. 1988. In vivo phosphorylation of sorghum leaf Phosphoenolpyruvate carboxylase. Biochimie 70:769-72

39. Hansen DE, Knowles JR. 1982. The stereochemical course at phosphorus of the reaction catalyzed by phosphoenolpyruvate carboxylase. J. Biol. Chem. 257:14795-98

40. Hermans J, Westhoff P. 1992. Homologous genes for the $\mathrm{C}_{4}$ isoform of phosphoenolpyruvate carboxylase in $\mathrm{a}_{3}$ and a $\mathrm{C}_{4}$ Flaveria species. Mol. Gen. Genet. 234:275-84

40A. Huber SC, Huber JL. 1996. Role and regulation of sucrose-phosphate synthase in higher plants Annu. Rev. Plant Physiol. Plant Mol. Biol. 47:431-44

41. Huber SC, Huber JL, McMichael RWJr . 1994. Control of plant enzyme activity by reversible protein phosphorylation. Int. Rev. Cytol. 149:47-98

42. Huber SC, Sugiyama T. 1986. Changes in sensitivity to effectors of maize leaf phosphoenolpyruvate carboxylase during light/dark transitions. Plant Physiol. 81:674-77

43. Hudspeth RL, Grula JW. 1989. Structure and expression of the maize gene encoding the phosphoenolpyruvate carboxylase isozyme involved in $\mathrm{C}_{4}$ photosynthesis. Plant Mol. Biol. 12:579-89

44. Hudspeth RL, Grula JW, Dai Z, Edwards GE, Ku MSB. 1992. Expression of maize Phosphoenolpyruvate carboxylase in transgenic tobacco: effects on biochemistry and physiology. Plant Physiol. 98:458-64

45. Iglesias AA, Andreo CS. 1984. On the molecular mechanism of maize phosphoenolpyruvate carboxylase activation by thiol compounds. Plant Physiol. 75:983-87

46. Inoue M, Hayashi M, Sugimoto M, Harada S, Kai Y, et al. 1989. First crystallization of a phosphoenolpyruvate carboxylase from Escherichia coli. J. Mol. Biol. 208:509-10

47. Izui K, Kawamura T, Okumura S, Toh H. 1992. Molecular evolution of Phosphoenolpyruvate carboxylase for $\mathrm{C}_{4}$ photosynthesis in maize. In Research in Photosynthesis, ed. N Murata, 3:827-30. Dordrecht: Kluwer

48. Janc JW, Cleland WW, O'Leary MH. 1992. Mechanistic studies of phosphoenolpyruvate carboxylase from Zea mays utilizing formate as an alternate substrate for bicarbonate. Biochemistry 31:6441-46

49. Janc JW, O'Leary MH, Cleland WW. 1992. A kinetic investigation of phosphoenolpyruvate carboxylase from Zea mays. Biochemistry 31:6421-26

50. Janc JW, Urbauer JL, O'Leary MH, Cleland WW. 1992. Mechanistic studies of phosphoenolpyruvate carboxylase from Zea mays with (Z)- and (E)-3-fluorophosphoenolpyruvate as substrates. Biochemistry 31:6432-40

51. Jiao JA, Chollet R. 1988. Light/dark regulation of maize leaf Phosphoenolpyruvate carboxylase by in vivo phosphorylation. Arch. Biochem. Biophys. 261:409-17

52. Jiao JA, Chollet R. 1989. Regulatory seryl-phosphorylation of $\mathrm{C}_{4}$ Phosphoenolpyruvate carboxylase by a soluble protein kinase from maize leaves. Arch. Biochem. Biophys. 269:526-35

53. Jiao JA, Chollet R. 1990. Regulatory phosphorylation of serine-15 in maize Phosphoenolpyruvate carboxylase by a $\mathrm{C}_{4}$-leaf protein-serine kinase. Arch. Biochem. Biophys. 283:300-5

54. Jiao JA, Chollet R. 1991. Posttranslational regulation of Phosphoenolpyruvate carboxylase in $\mathrm{C}_{4}$ and Crassulacean acid metabolism plants. Plant Physiol. 95:981-85

55. Jiao JA, Chollet R. 1992. Light activation of maize Phosphoenolpyruvate carboxylase protein-serine kinase activity is inhibited by mesophyll and bundle sheath-directed photosynthesis inhibitors. Plant Physiol. 98:152-56

56. Jiao JA, Echevarría C, Vidal J, Chollet R. 1991. Protein turnover as a component in the light/dark regulation of Phosphoenolpyruvate carboxylase protein-serine kinase activity in $\mathrm{C}_{4}$ plants. Proc. Natl. Acad. Sci USA 88:2712-15

57. Jiao JA, Podestá FE, Chollet R, O'Leary MH, Andreo CS. 1990. Isolation and sequence of an active-site peptide from maize leaf Phosphoenolpyruvate carboxylase inactivated by pyridoxal 5'- 
phosphate. Biochim. Biophys. Acta 1041:291-95

58. Jiao JA, Vidal J, Echevarría C, Chollet R. 1991. In vivo regulatory phosphorylation site in $C_{4}$-leaf Phosphoenolpyruvate carboxylase from maize and sorghum. Plant Physiol. 96:297-301

59. Kano-Murakami Y, Matsuoka M. 1992. Gene expression of PEP carboxylase gene. See Ref. $\underline{47}$ 3:843-46

60. Karabourniotis G, Manetas Y, Gavalas NA. 1983. Photoregulation of phosphoenolpyruvate carboxylase in Salsola soda L. and other $\mathrm{C}_{4}$ plants. Plant Physiol. 73:735-39

61. Kawamura T, Shigesada K, Toh H, Okumura S, Yanagisawa S, Izui K. 1992. Molecular evolution of phosphoenolpyruvate carboxylase for $\mathrm{C}_{4}$ photosynthesis in maize: comparison of its cDNA sequence with a newly isolated cDNA encoding an isozyme involved in the anaplerotic function. J. Biochem. 112:147-54

62. Kogami H, Shono M, Koike T, Yanagisawa S, Izui K, et al. 1994. Molecular and physiological evaluation of transgenic tobacco plants expressing a maize Phosphoenolpyruvate carboxylase gene under the control of the cauliflower mosaic virus 35S promoter. Transgenic Res. 3:287-96

63. Krüger I, Kluge M. 1987. Diurnal changes in the regulatory properties of phosphoenolpyruvate carboxylase in plants: Are alterations in the quaternary structure involved? Bot. Acta 101:24-27

64. Langdale JA, Taylor WC, Nelson T. 1991. Cell-specific accumulation of maize phosphoenolpyruvate carboxylase is correlated with demethylation at a specific site $>3 \mathrm{~kb}$ upstream of the gene. Mol. Gen. Genet. 225:49-55

65. Law RD, Plaxton WC. 1995. Purification and characterization of a novel phosphoenolpyruvate carboxylase from banana fruit. Biochem. J. 307:807-16

66. Leegood RC, Osmond CB. 1990. The flux of metabolites in $C_{4}$ and CAM plants. In Plant Physiology, Biochemistry and Molecular Biology, ed. DT Dennis, DH Turpin, pp. 274-98. Essex: Longman Sci. Tech.

67. Lepiniec L, Keryer E, Philippe H, Gadal P, Crétin C. 1993. Sorghum phosphoenolpyruvate carboxylase gene family: structure, function and molecular evolution. Plant Mol. Biol. 21:487-502

68. Lepiniec L, Vidal J, Chollet R, Gadal P, Crétin C. 1994. Phosphoenolpyruvate carboxylase: structure, regulation and evolution. Plant Sci. 99:111-24

69. Li B, Chollet R. 1993. Resolution and identification of $C_{4}$ Phosphoenolpyruvate-carboxylase protein-kinase polypeptides and their reversible light activation in maize leaves. Arch. Biochem. Biophys. 307:416-19

70. Li B, Chollet R. 1994. Salt induction and the partial purification/characterization of Phosphoenolpyruvate carboxylase protein-serine kinase from an inducible Crassulacean-acid-metabolism (CAM) plant, Mesembryanthemum crytallinum L. Arch. Biochem. Biophys. 314:247-54

71. Liu J, Peliska JA, O'Leary MH. 1990. Synthesis and study of (Z)-3-chlorophosphoenolpyruvate. Arch. Biochem. Biophys. 277:143-48

72. Maruyama H, Easterday RL, Chang HC, Lane MD. 1966. The enzymatic carboxylation of phosphoenolpyruvate. I. Purification and properties of phosphoenolpyruvate carboxylase. J. Biol. Chem. 241:2405-12

73. Matsuoka M, Kyozuka J, Shimamoto K, Kano-Murakami Y. 1994. The promoters of two carboxylases in a $\mathrm{C}_{4}$ plant (maize) direct cell-specific, light-regulated expression in a $\mathrm{C}_{3}$ plant (rice). Plant J. 6:311-19

74. Matsuoka M, Minami E. 1989. Complete structure of the gene for Phosphoenolpyruvate carboxylase from maize. Eur. J. Biochem. 181:593-98

75. Matsuoka M, Sanada Y. 1991. Expression of photosynthetic genes from the $C_{4}$ plant, maize, in tobacco. Mol. Gen. Genet. 225:411-19

76. McElwain EF, Bohnert HJ, Thomas JC. 1992. Light moderates the induction of Phosphoenolpyruvate carboxylase by $\mathrm{NaCl}$ and abscisic acid in Mesembryanthemum crystallinum. Plant Physiol. 99:1261-64

77. McNaughton GAL, Fewson CA, Wilkins MB, Nimmo HG. 1989. Purification, oligomerization state and malate sensitivity of maize leaf phosphoenolpyruvate carboxylase. Biochem. J. 261:349-55

78. McNaughton GAL, MacKintosh C, Fewson CA, Wilkins MB, Nimmo HG. 1991. Illumination in- 
creases the phosphorylation state of maize leaf Phosphoenolpyruvate carboxylase by causing an increase in the activity of a protein kinase. Biochim. Biophys. Acta 1093:189-95

79. Meyer CR, Willeford KO, Wedding RT. 1991. Regulation of Phosphoenolpyruvate carboxylase from Crassula argentea: effect of incubation with ligands and dilution on oligomeric state, activity, and allosteric properties. Arch. Biochem. Biophys. 288:343-49

79A. Nakamura T, Yoshioka I, Takahashi M, Toh H, Izui K. 1995. Cloning and sequence analysis of the gene for phosphoenolpyruvate carboxylase from an extreme thermophile, Thermus sp. J. Biochem. 118:319-24

79B. Newman T, de Bruijn FJ, Green P, Keegstra K, Kende H, et al. 1994. Genes galore: a summary of methods for accessing results from a large-scale partial sequencing of anonymous Arabidopsis cDNA clones. Plant Physiol. 106:1241-55

80. Nimmo GA, McNaughton GAL, Fewson CA, Wilkins MB, Nimmo HG. 1987. Changes in the kinetic properties and phosphorylation state of Phosphoenolpyruvate carboxylase in Zea mays leaves in response to light and dark. FEBS Lett. 213:18-22

81. Nimmo GA, Nimmo HG, Fewson CA, Wilkins MB. 1984. Diurnal changes in the properties of phosphoenolpyruvate carboxylase in Bryophyllum leaves: a possible covalent modification. FEBS Lett. 178:199-203

82. Nimmo GA, Nimmo HG, Hamilton ID, Fewson CA, Wilkins MB. 1986. Purification of the phosphorylated night form and dephosphorylated day form of phosphoenolpyruvate carboxylase from Bryophyllum fedtschenkoi. Biochem. J. 239:213-20

83. Nimmo GA, Wilkins MB, Fewson CA, Nimmo HG. 1987. Persistent circadian rhythms in the phosphorylation state of phosphoenolpyruvate carboxylase from Bryophyllum fedtschenkoi leaves and in its sensitivity to inhibition by malate. Planta 170:408-15

84. Nimmo HG. 1993. The regulation of phosphoenolpyruvate carboxylase by reversible phosphorylation. In Society for Experimental Biology Seminar Series 53: Post-translational Modifications in Plants, ed. NH Battey, HG Dickinson, AM Hetherington, pp. 161-70. London: Cambridge Univ. Press

85. Ogawa N, Okumura S, Izui K. 1992. A Ca ${ }^{2+}$-dependent protein kinase phosphorylates phosphoenolpyruvate carboxylase in maize. FEBS Lett. 302:86-88

86. O'Laughlin JT. 1988. Mechanistic probes of the catalytic activity of the enzyme phosphoenolpyruvate carboxylase. PhD thesis. Univ. Wis., Madison. 135 pp.

87. O’Leary MH. 1982. Phosphoenolpyruvate carboxylase: an enzymologist's view. Annu. Rev. Plant Physiol. 33:297-315

88. O'Leary MH, Hermes JD. 1987. Determination of substrate specificity of carboxylases by nuclear magnetic resonance. Anal. Biochem. 162:358-62

89. O'Leary MH, Rife JE, Slater JD. 1981. Kinetic and isotope effect studies of maize phosphoenolpyruvate carboxylase. Biochemistry 20:7308-14

90. Outlaw WHJr . 1990. Kinetic properties of guard-cell Phosphoenolpyruvate carboxylase. Biochem. Physiol. Pflanzen 186:317-25

91. Pacquit V, Santi S, Crétin C, Bui VL, Vidal J, Gadal P. 1993. Production and properties of recombinant $\mathrm{C}_{3}$-type Phosphoenolpyruvate carboxylase from Sorghum vulgare: in vitro phosphorylation by leaf and root PyrPC protein serine kinases. Biochem. Biophys. Res. Commun. 197:1415-23

92. Pathirana SM, Vance CP, Miller SS, Gantt JS. 1992. Alfalfa root nodule phosphoenolpyruvate carboxylase: characterization of the cDNA and expression in effective and plant-controlled ineffective nodules. Plant Mol. Biol. 20:437-50

93. Peliska JA, O'Leary MH. 1989. Sulfuryl transfer catalyzed by pyruvate kinase. Biochemistry 28:1604-11

94. Pierre JN, Pacquit V, Vidal J, Gadal P. 1992. Regulatory phosphorylation of Phosphoenolpyruvate carboxylase in protoplasts from Sorghum mesophyll cells and the role of $\mathrm{pH}$ and $\mathrm{Ca}^{2+}$ as possible components of the light-transduction pathway. Eur. J. Biochem. 210:531-37

95. Poetsch W, Hermans J, Westhoff P. 1991. Multiple cDNAs of phosphoenolpyruvate carboxylase in the $\mathrm{C}_{4}$ dicot Flaveria trinervia. FEBS Lett. 292:133-36

96. Rajagopalan AV, Devi MT, Raghavendra AS. 1994. Molecular biology of $C_{4}$ Phosphoenolpyruvate carboxylase: structure, regulation and genetic engineering. Photosynth. Res. 39:115-35 
96A. Relle M, Wild A. 1994. EMBL/GenBank/DDBJ databases. Accession number X79090

97. Rose IA, O'Connell EL, Noce P, Utter MF, Wood HG, et al. 1969. Stereochemistry of the enzymatic carboxylation of phosphoenolpyruvate. J. Biol. Chem. 244:6130-33

98. Samaras Y, Manetas Y, Gavalas NA. 1988. Effects of temperature and photosynthetic inhibitors on light activation of $C_{4}$-phosphoenolpyruvate carboxylase. Photosynth. Res. 16:233-42

98A. Schaeffer HJ, Forsthoefel NR, Cushman JC. 1995. Identification of enhancer and silencer regions involved in salt-responsive expression of Crassulacean acid metabolism (CAM) genes in the facultative halophyte Mesembryanthemum crystallinum. Plant Mol. Biol. 28:205-18

99. Schäffner AR, Sheen J. 1992. Maize $C_{4}$ photosynthesis involves differential regulation of phosphoenolpyruvate carboxylase genes. Plant J. 2:221-32

100. Schuller KA, Plaxton WC, Turpin DH. 1990. Regulation of Phosphoenolpyruvate carboxylase from the green alga Selenastrum minutum: properties associated with replenishment of tricarboxylic acid cycle intermediates during ammonium assimilation. Plant Physiol. 93:1303-11

101. Schuller KA, Turpin DH, Plaxton WC. 1990. Metabolite regulation of partially purified soybean nodule Phosphoenolpyruvate carboxylase. Plant Physiol. 94:1429-35

102. Schuller KA, Werner D. 1993. Phosphorylation of soybean (Glycine max L.) nodule Phosphoenolpyruvate carboxylase in vitro decreases sensitivity to inhibition by l-malate. Plant Physiol. 101:1267-73

103. Sikkema KD, O'Leary MH. 1988. Synthesis and study of phosphoenolthiopyruvate. Biochemistry 27:1342-47

104. Stiborová M. 1988. Phosphoenolpyruvate carboxylase: the key enzyme of $\mathrm{C}_{4}$-photosynthesis. Photosynthetica 22:240-63

105. Stockhaus J, Poetsch W, Steinmüller K, Westhoff P. 1994. Evolution of the $\mathrm{C}_{4}$ phosphoenolpyruvate carboxylase promoter of the $\mathrm{C}_{4}$ dicot Flaveria trinervia: an expression analysis in the $\mathrm{C}_{3}$ plant tobacco. Mol. Gen. Genet. 245:286-93

106. Suzuki I, Crétin C, Omata T, Sugiyama T. 1994. Transcriptional and posttranscriptional regulation of nitrogen-responding expression of Phosphoenolpyruvate carboxylase gene in maize. Plant Physiol. 105:1223-29

107. Tagu D, Crétin C, Bergounioux C, Lepiniec L, Gadal P. 1991. Transcription of a Sorghum phosphoenolpyruvate carboxylase gene in transgenic tobacco leaves: maturation of monocot premRNA by dicot cells. Plant Cell Rep. 9:688-90

108. Taybi T, Sotta B, Gehrig H, Guclu S, Kluge M, Brulfert J. 1995. Differential effects of abscisic acid on phosphoenolpyruvate carboxylase and CAM operation in Kalanchoë blossfeldiana. Bot. Acta 108:240-46

109. Terada K, Izui K. 1991. Site-directed mutagenesis of the conserved histidine residue of Phosphoenolpyruvate carboxylase. His138 is essential for the second partial reaction. Eur. J. Biochem. 202:797-803

110. Terada K, Kai T, Okuno S, Fujisawa H, Izui K. 1990. Maize leaf phosphoenolpyruvate carboxylase: phosphorylation of Ser ${ }^{15}$ with a mammalian cyclic AMP-dependent protein kinase diminishes sensitivity to inhibition by malate. FEBS Lett. 259:241-44

111. Terada K, Murata T, Izui K. 1991. Site-directed mutagenesis of phosphoenolpyruvate carboxylase from E. coli: the role of $\mathrm{His}^{579}$ in the catalytic and regulatory functions. J. Biochem. 109:49-54

112. Terada K, Yano M, Izui K. 1992. Functional analysis of PEP carboxylase by site-directed mutagenesis. See Ref. 47, pp. 3:823-26

113. Thomas M, Crétin C, Vidal J, Keryer E, Gadal P, Monsinger E. 1990. Light-regulation of phosphoenolpyruvate carboxylase mRNA in leaves of $\mathrm{C}_{4}$ plants: evidence for phytochrome control on transcription during greening and for rhythmicity. Plant Sci. 69:65-78

114. Toh H, Kawamura T, Izui K. 1994. Molecular evolution of Phosphoenolpyruvate carboxylase. Plant Cell Environ. 17:31-43

115. Vance CP, Gregerson RG, Robinson DL, Miller SS, Gantt JS. 1994. Primary assimilation of nitrogen in alfalfa nodules: molecular features of the enzymes involved. Plant Sci. 101:51-64

116. Van Quy L, Foyer C, Champigny ML. 1991. Effect of light and $\mathrm{NO}_{3}{ }^{-}$on wheat leaf Phosphoenolpyruvate carboxylase activity: evidence for covalent modulation of the $\mathrm{C}_{3}$ enzyme. Plant Physiol. 97:1476-82 
117. Vidal J, Pierre J-N, Echevarria C. 1996. The regulatory phosphorylation of $\mathrm{C}_{4}$ Phosphoenolpyruvate carboxylase: a cardinal event in $\mathrm{C}_{4}$ photosynthesis. In Plant Gene Research, ed. ES Dennis, B Hohn, PJ King, J Schell, DPS Verma. New York: Springer-Verlag. In press

118. Walsh C. 1979. Enzymatic Reaction Mechanisms, pp. 705-7. San Francisco: Freeman

119. Wang YH, Chollet R. 1993. In vitro phosphorylation of purified tobacco-leaf Phosphoenolpyruvate carboxylase. FEBS Lett. 328:215-18

120. Wang YH, Chollet R. 1993. Partial purification and characterization of Phosphoenolpyruvate carboxylase protein-serine kinase from illuminated maize leaves. Arch. Biochem. Biophys. 304:496-502

121. Wang YH, Duff SMG, Lepiniec L, Crétin C, Sarath G, et al. 1992. Site-directed mutagenesis of the phosphorylatable serine $\left(\mathrm{Ser}^{8}\right)$ in $\mathrm{C}_{4}$ Phosphoenolpyruvate carboxylase from sorghum: the effect of negative charge at position 8. J. Biol. Chem. 267:16759-62

122. Weigend M, Hincha DK. 1992. Quaternary structure of phosphoenolpyruvate carboxylase from CAM- $\mathrm{C}_{4}$-and $\mathrm{C}_{3}$-plants: no evidence for diurnal changes in oligomeric state. J. Plant Physiol. 140:653-60

122A. Wera S, Hemmings BA. 1995. Serine/threonine protein phosphatases. Biochem. J. 311:17-29

123. Willeford KO, Wedding RT. 1992. Oligomerization and regulation of higher plant Phosphoenolpyruvate carboxylase. Plant Physiol. 99:755-58

124. Winkler FJ, Schmidt H-L, Wirth E, Latzko E, Lenhart B, Ziegler H. 1983. Temperature, pH and enzyme-source dependence of the $\mathrm{HCO}_{3}{ }^{-}$carbon isotope effect on the phosphoenolpyruvate carboxylase reaction. Physiol. Vég. 21:889-95

125. Winter K. 1982. Properties of phosphoenolpyruvate carboxylase in rapidly prepared, desalted leaf extracts of the Crassulacean acid metabolism plant Mesembryanthemum crystallinum L. Planta 154:298-308

126. Wirsching P, O’Leary MH. 1988. 1-Carboxyallenyl phosphate, an allenic analogue of phosphoenolpyruvate. Biochemistry 27:1355-60

127. Wu MX, Meyer CR, Willeford KO, Wedding RT. 1990. Regulation of the aggregation state of maize Phosphoenolpyruvate carboxylase: evidence from dynamic light-scattering measurements. Arch. Biochem. Biophys. 281:324-29

128. Wu MX, Wedding RT. 1985. Regulation of phosphoenolpyruvate carboxylase from Crassula by interconversion of oligomeric forms. Arch. Biochem. Biophys. 240:655-62

129. Wu MX, Wedding RT. 1987. Regulation of phosphoenolpyruvate carboxylase from Crassula argentea: further evidence on the dimer-tetramer interconversion. Plant Physiol. 84:1080-83

130. Yanagisawa S, Izui K. 1992. Maize nuclear factors interacting with the $C_{4}$ photosynthetic phosphoenolpyruvate carboxylase gene promoter. See Reference \# $\underline{47}, 3: 839-42$

131. Yanagisawa S, Izui K. 1993. Molecular cloning of two DNA-binding proteins of maize that are structurally different but interact with the same sequence motif. J. Biol. Chem. 268:16028-36

132. Yanagisawa S, Izui K, Yamaguchi Y, Shigesada K, Katsuki H. 1988. Further analysis of cDNA clones for maize Phosphoenolpyruvate carboxylase involved in $\mathrm{C}_{4}$ photosynthesis: nucleotide sequence of entire open reading frame and evidence for polyadenylation of mRNA at multiple sites in vivo. FEBS Lett. 229:107-10

133. Yanai Y, Okumura S, Shimada H. 1994. Structure of Brassica napus Phosphoenolpyruvate carboxylase genes: missing introns causing polymorphisms among gene family members. Biosci. Biotech. Biochem. 58:950-53

134. Yano M, Terada K, Umiji K, Izui K. 1995. Catalytic role of an arginine residue in the highly conserved and unique sequence of phosphoenolpyruvate carboxylase. J. Biochem. 117:1196-1200

135. Zhang SQ, Outlaw WHJr, Chollet R. 1994. Lessened malate inhibition of guard-cell Phosphoenolpyruvate carboxylase velocity during stomatal opening. FEBS Lett. 352:45-48

136. Zhang XQ, Li B, Chollet R. 1995. In vivo regulatory phosphorylation of soybean nodule Phosphoenolpyruvate carboxylase. Plant Physiol. 108:1561-68 